\title{
EFFECTIVENESS OF BACILLUS THURINGIENSIS STRAINS AGAINST SPODOPTERA FRUGIPERDA (LEPIDOPTERA: NOCTUIDAE)
}

\author{
Ricardo Antonio Polanczyk ${ }^{1}$; Rogério Fernando Pires da Silva ${ }^{1}$; Lidia Mariana Fiuza ${ }^{2 *}$
}

${ }^{1}$ Health Plant Department, School of Agronomy, Universidade Federal do Rio Grande do Sul, RS, Brasil; ${ }^{2}$ Centro de Biotecnologia do Estado do Rio Grande do Sul, Universidade do Rio Grande do Sul e Departamento de Microbiologia, UNISINOS, RS, Brasil

Submitted: August 13, 1999; Returned to authors for corrections: December 16, 1999; Approved: September 13, 2000

\begin{abstract}
The fall armyworm (Spodoptera frugiperda) is one of the most important pests of maize, causing up to $20 \%$ production losses when defoliation occurs near to flowering, or even complete destruction of plants. Among the alternatives to control this pest, the use of Bacillus thuringiensis (Bt) has gained attention due to its efficiency and low impact on natural enemies. Strains Bt dendrolimus HD 37, Bt aizawai HD 68, Bt kurstaki HD 73, Bt darmstadiensis HD 146, and Bt thuringiensis 4412 were tested against second instar larvae in in vivo assays. Suspensions of Bt aizawai HD 68 and Bt thuringiensis 4412 , containing $3 \times 10^{8}$ cells $/ \mathrm{ml}$, induced mortality of $100 \%$ and $80.4 \%$, respectively. To test virulence, cell concentrations of $8 \times$ $10^{5}$ to $3 \times 10^{8}$ cells $/ \mathrm{ml}$ of strains Bt aizawai HD 68 and Bt thuringiensis 4412 were applied on the second instar larvae: $\mathrm{LC}_{50}$ were $6.7 \times 10^{6}$ and $8.6 \times 10^{6}$ cells $/ \mathrm{ml}$, respectively.
\end{abstract}

Key words: Bacillus thuringiensis, Spodoptera frugiperda, biological control, bioassays, fall armyworm

\section{INTRODUCTION}

The fall armyworm (Spodoptera frugiperda Smith \& Abbot), that attacks various cultures is one of the most important pests of maize in the Americas (17), causing about $20 \%$ production losses in Brazil (6). Although the use of chemicals is the prevailing method to control this pest, problems such as ecological disequilibrium, pollution, risks during application and high costs are present (16). Furthermore, the insecticides kill the fall armyworm natural enemies, favoring rapid reinfestation with serious damage to the culture (6). In fact, all these questions increased the interest in alternative strategies to manage this pest.

Nowadays, some methods, solely or together, get the satisfactory control of $S$. frugiperda. Among the entomopathogenic agents used in biological control of lepidopterous pests the Bacillus thuringiensis Berliner bacterium $(B t)$ has gained special attention as an alternative method $(2,11)$.
This microorganism acts in the insect gut due to cristals, composed by protoxins, discharged in the gut due to the alkaline $\mathrm{pH}$ that causes solubilization. These protoxins, in presence of digestive enzymes, are converted in toxic polypetides (deltaendotoxins). The activated toxins cross the peritrofic membrane, join to specific receptors in apical membrane of columnar cells of midgut, and insert themselves into the membrane $(9,11)$. The formation of pores disrupts the ionic gradients and osmotic balance in the apical membrane, resulting in cell swelling and lysis. This phenomenon leds to massive destruction of epithelium, causing death of larva (12).

Some time ago, the efficacy of this microorganism against $S$. frugiperda was considered questionable, but more recently the increment in researches on the use of $B t$ against this lepidopterous brought some interesting results $(4,10)$. The objective of this work was to report the selection of $B t$ strains with potential to control the fall armyworm. They could be used in the formulation of new biopesticides or in genetic transformation of host plants.

\footnotetext{
* Corresponding author. Mailing address: Laboratório de Microbiologia, Centro 2, UNISINOS, Caixa Postal 275, CEP: 93022-000, São Leopoldo, RS, Brasil. Email: fiuza@cirrus.unisinos.br
} 


\section{MATERIALS AND METHODS}

Insects: S. frugiperda larvae were obtained from maize fields in Viamão (South Brazil) and reared in Bowling diet (5). The insects used in these assays belonged to the $20^{\text {th }}$ generation and were mantained at $25 \pm 2{ }^{\circ} \mathrm{C}$ with $65 \pm 5 \%$ relative humidity and $12 \mathrm{~h}$ photoperiod.

Selective assays: These assays were carried out in a Biological Oxigen Demand chamber, in the same conditions described above. Bt dendrolimus HD 37 was provided by the Institut Pasteur, Paris and Bt aizawai HD 68, Bt kurstaki HD 73, Bt darmstadiensis HD 146 and Bt thuringiensis 4412 strains were provided by Plant Genetic Systems, Gent. They were grown in Usual Glicosed Medium (8) at $28^{\circ} \mathrm{C}$ and $180 \mathrm{rpm}$ for $48 \mathrm{~h}$. The suspension was centrifuged at 5,000 rpm and washed 3 times with sterilized water. The concentration of bacterial spores was determined in a Neubaeur chamber using phase contrast microscopy at 400x. $100 \mathrm{ml}$ of the both containing of $3 \times 10^{8}$ cells $/ \mathrm{ml}$ were added to the surface of artificial diet previously put in mini-plates ( $30 \mathrm{~mm}$ of diameter), where larvae of $2^{\text {nd }}$ instar of $S$. frugiperda were individualized (20 insects per strain). In controls, the broth was replaced by $100 \mu \mathrm{l}$ of sterile water. The mortality was evaluated up to seven days after treatment. The data were corrected according to Abbot (1) and submitted to Duncan's $t$ test $(\mathrm{P}=0.05)$.

$L C_{50}$ assays: The virulence of Bt aizawai HD 68 and $B t$ thuringiensis 4412 was evaluated by $\mathrm{LC}_{50}$ assays, using $8 \mathrm{x}$ $10^{5}, 3 \times 10^{6}, 8 \times 10^{6}, 3 \times 10^{7}, 8 \times 10^{7}$ and $3 \times 10^{8}$ cells $/ \mathrm{ml}$ and control. Three replications were carried out, totalizing 1,050 insects per strain. To achieve the initial concentration of $3 \mathrm{x}$ $10^{8}$ cells $/ \mathrm{ml}$, the above mentioned method for cell counting was used. All other cell concentrations was obtained through dilutions of this suspension. The exact number of spores was determined in a Neubaeur chamber. The amount of suspension and the method for growth of microorganism were the same as in selective assays. The data were analyzed by Polo-PC (LeOra Software 1987).

Subletal effects: The possible effects of the strains on insects were verified through visual comparison between growth of surviving larvae and control insects.

\section{RESULTS AND DISCUSSION}

The in vivo activities of $B t$ strains tested on second instar S. frugiperda larvae are shown in Fig. 1. Bt thuringiensis 4412 and Bt aizawai HD 68 strains were the most pathogenic causing $80.40 \%$ and $100 \%$ of mortality, respectively. These strains were statistically different to others but not between them (Duncan, $5 \%$ ). Similar results were obtained by Hernandez (10) for subspecies Bt aizawai, Bt thuringiensis and Bt kurstaki, observing mortality of $80 \%, 100 \%$ and $70 \%$, respectively, to 3 x $10^{7}$ cells $/ \mathrm{ml}$.

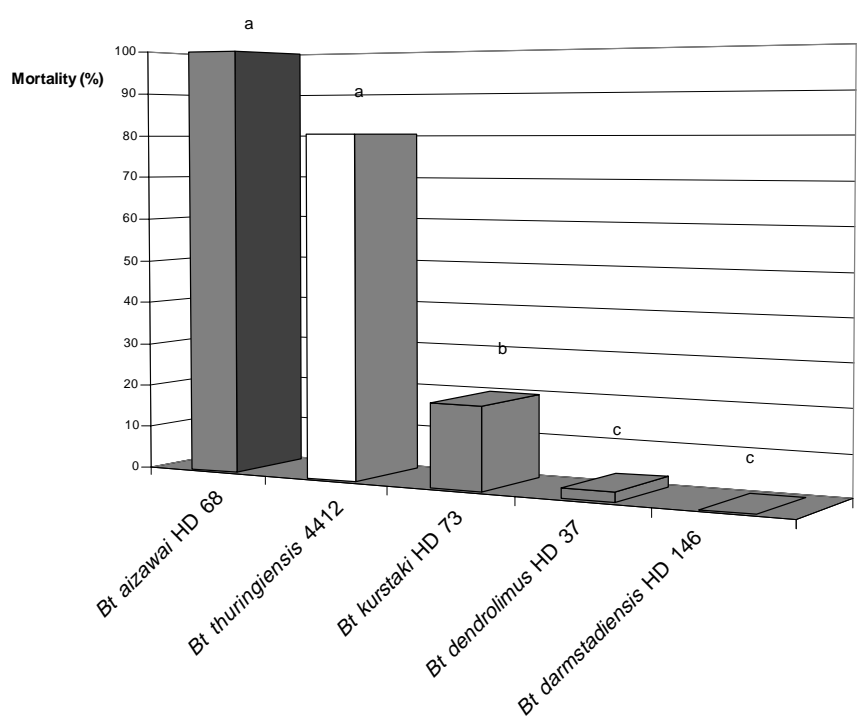

Figure 1. Mortality in selective assays of Spodoptera frugiperda second instar larvae and Bacillus thuringiensis strains at $3 \times 10^{8}$ cells $/ \mathrm{ml}$ concentration.

The virulence assays showed that Bt aizawai HD 68 was the most active strain, with an $\mathrm{LC}_{50}$ of $6.7 \times 10^{6} \mathrm{cells} / \mathrm{ml} . \mathrm{Bt}$ thuringiensis 4412 presented an $\mathrm{LC}_{50}$ of $8.6 \times 10^{6}$ cells $/ \mathrm{ml}$ (Table 1). These $\mathrm{LC}_{50}$ values showed that a concentration $42.0 \%$ higher of Bt thuringiensis 4412 than the other strain was necessary to kill $50.0 \%$ of a $S$. frugiperda population in a certain period. Fig. 2 compares the virulence of the strains and shows that Bt aizawai HD 68 requires a lower concentration to be letal to $100 \%$ of larvae population.

The differences in toxicity of these strains to S. frugiperda may be related to the composition of cristals and their toxic potential. Bt aizawai HD 68 has two genes ( $\operatorname{cryIA}(a)$, cryID) related to toxicity, while Bt thuringiensis 4412 has only one

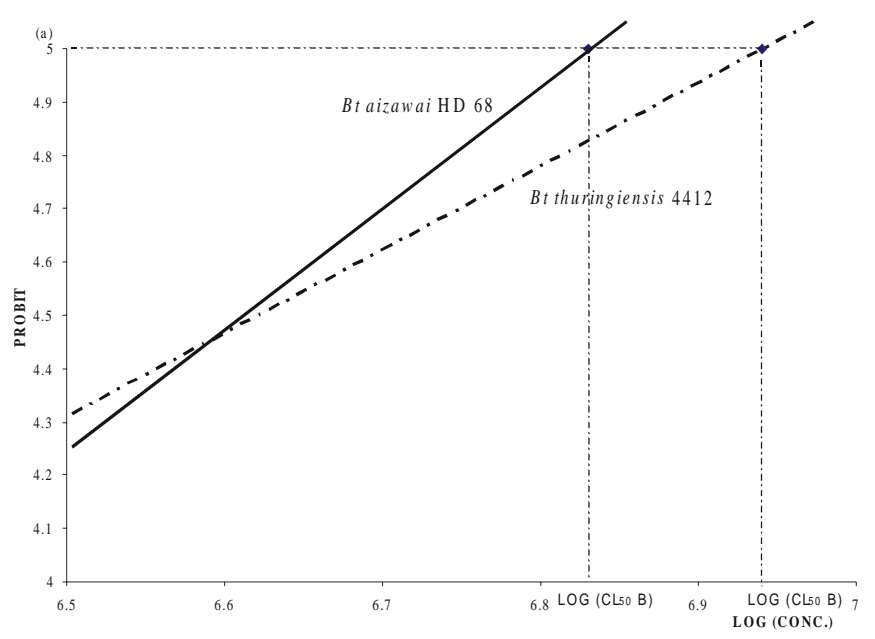

Figure 2. Comparative virulence of Bt aizawai HD 68 and $B t$ thuringiensis 4412 to Spodoptera frugiperda second instar larvae. 
Table 1. $\mathrm{LC}_{50}$ of Bacillus thuringiensis strains to Spodoptera frugiperda second instar larvae.

\begin{tabular}{cccc}
\hline Strains & $\mathrm{LC}_{50} *$ & $(\mathrm{LL}-s \mathrm{~L})$ & Equation \\
\hline Bt aizawai HD 68 & $6.7 \times 10^{6}$ & $4.7 \times 10^{6}-9.2 \times 10^{6}$ & $\mathrm{y}=-0.412+0.792 \times$ \\
Bt thuringiensis 4412 & $8.6 \times 10^{6}$ & $6.0 \times 10^{6}-12.0 \times 10^{6}$ & $\mathrm{y}=0.414+0.660 \times$ \\
\hline
\end{tabular}

* Results obtained using 1,050 larvae per strain.

$(l \mathrm{~L}-s \mathrm{~L})=$ Lower and superior limits (values) per $\mathrm{LC}_{50}$.

(cryIB) (3). $\mathrm{LC}_{50}$ values of $77 \mathrm{ng} / \mathrm{cm}^{2}$ for cryID and above $2,000 \mathrm{ng} / \mathrm{cm}^{2}$ for cryIA $(a, b, c)$ were observed (3). Chak et al. (7) described a new strain of Bt with cryI $(a, b)$, cryIC and cryID genes, and emphasized that the high activity of Bt aizawai strains to $S$. frugiperda may be related to interactions between cryIA and cryID genes.

It must be pointed out that although the mortality to the selected strains in concentration of $3 \times 10^{8}$ cells $/ \mathrm{ml}$ was incomplete, the surviving larvae had their development delayed, and didn't reach the fourth instar. From a practical point of view, the control can be considered effective, because the damage potential of surviving larvae was affected. This enhanced the possibility to use moderated toxic proteins as a helpful tool to control $S$. frugiperda in integrated pest management systems in maize. The subletal effects of $B t$ on $S$. frugiperda (13), S. littoralis (15) and S. exigua (14) were pointed out in other studies, where subletal doses caused reduction in consumption and delay in development. However, these effects were temporary, and the intensity decreased with the growth of larvae.

The high virulence presented by Bt aizawai HD 68 and $B t$ thuringiensis 4412 to $S$. frugiperda indicates their application in integrated pest management systems. The great majority of surviving larvae had their development delayed by the action of these pathogenic microorganisms. This aspect is very important, but rarely considered in the evaluation of effectiveness of biological agents.

\section{ACKNOWLEDGEMENTS}

We are especially grateful to Marnix Peferoen (Plant Genetic Systems, Gent, Belgium) and Jean-François Charles (Institut Pasteur, Paris, France) for providing the Bacillus thuringiensis strains. We are also thank Andresa P. de Lucho and Ana Paula G. de Castro, students from School of Agronomy/UFRGS (Porto Alegre, Brazil), for their assistance in insect rearing. This research was supported by $\mathrm{CNPq}$ (Brazil).

\section{REFERENCES}

1. Abbot, W. S. A method of computing the effectiveness insecticide. J. Ec. Ent., 18: 265-267, 1925.

2. Alves, S. B.; Moino Jr., A.; Almeida, J. E. M. Desenvolvimento, potencial de uso e comercialização de produtos microbianos. In: Alves, S. B. (ed). Controle microbiano de insetos. FEALQ, São Paulo, 1998. p. 1143-1163.

3. Aranda, E.; Sanchez, J.; Peferoen, M.; Güereca, L; Bravo, A. Interactions of Bacillus thuringiensis crystal proteins with the midgut epithelial cells of Spodoptera frugiperda (Lepidoptera: Noctuidae). J. Invert. Pathol., 68: 203 212, 1996.

4. Bohorova, N.; Maciel, A. M.; Brito, R. M.; Aguilart, L.; Ibarra, J.E.; Hoisinggton, D. Selection and characterization of mexican strains of Bacillus thuringiensis active against four major lepidopteran maize pests. Entomoph.,41:153-165, 1996.

5. Bowling, C. C. Rearing of two lepidopterous pests of rice on a common artificial diet. Ann. Entomol. Soc. America, 60: 1215-1216, 1967.

6. Cruz, I. Manejo de pragas de milho no Brasil. Curso Sobre Manejo y Control de Plagas en Maiz y Sorgo, Sete Lagoas, 1988, p.17-31.

7. Chak, K.F.; Chao, D.C.; Tseng, M.Y. et al. Determination and distribution of cry-type genes of Bacillus thuringiensis isolates from Taiwan. Appl. Environ. Microbiol., 60:2415-2420, 1994.

8. De Barjac, H.; Lecadet, M.M. Dosage biochimique d'exotoxine thermostable de. Bacillus thuringiensis d'après l'inhibition d'ARN-polymerases bacteriennes. C. R. Acad. Sci., 282:2119-2122, 1976.

9. Fiuza, L.M.; Nielsen-Leroux, C.; Gozé E.; Frutos, R.; Charles, J. F. Binding of Bacillus thuringiensis Cry1 toxins to the midgut brush border membrane vesicles of Chilo supressalis (Lepidoptera: Pyralidae): Evidence of shared binding sites. Appl. Environ. Microbiol., 62:1544-1549, 1996.

10. Hernandez, J.L.L. Évaluation de la toxicité de Bacillus thuringiensis sur Spodoptera frugiperda. Entomoph., 32:163-171, 1988.

11. Höfte, H.; Whiteley, H. R. Insecticidal crystal proteins of Bacillus thuringiensis. Microbiol. Rev., 53:242-255, 1978.

12. Knowles, B. H. Mechanism of action of Bacillus thuringiensis insecticidal d-endotoxins. Adv. Insect Physiol., 24:275-308, 1994.

13. Lambert, B.; Buysse, L.; Decock, C.; Jansens, S.; Piens, C.; Saey, B.; Seurinck, J.; Van Audenhove, K.; Van Rie, J.; Van Vliet, A.; Peferoen, M. A Bacillus thuringiensis insecticidal crystal protein with high activity against members of the family Noctuidae. Appl. Environ. Microbiol., 62:80-86, 1996.

14. Lopes Lastra, C. C.; Boucias, D. G.; Soares Jr., G. G. Bacillus thuringiensis endotoxin effects on Spodoptera exigua and Spodoptera frugiperda larva infected with baculovirus. Env. Entomol., 24:239-242, 1995.

15. Regev, A.; Keller, M.; Strizhov, N.; Shen, B.; Prudovsky, E.; Chet, I.; Ginzberg, I.; Koncz-Kalman, Z.; Koncz, C.; Schell, J.; Zilberstein, A. Synergistic activity of a Bacillus thuringiensis d-endotoxin and a bacterial endochitinase against Spodoptera littoralis larvae. Appl. Environ. Microbiol.,62:3581-3386, 1996.

16. Valicente, F. H. Levantamento dos inimigos naturais de Spodoptera frugiperda (J. E. Smith, 1797) (Lepidoptera: Noctuidae) em diferentes regiões do Estado de Minas Gerais. An. Soc. Entomol. Brasil, 18: 119-130, 1989.

17. Wiseman, B. R., Painter, R. H., Wassom, C. E. Detecting corn seedling differences on the greenhouse by visual classification of damage by the fall armyworm. J. Ec. Ent., 59:1211-1214, 1966. 